Klinik Araştırma/Clinical Research

\title{
Giresun ilinde fındık tarımı ile uğraşan çiftçiler arasındaki ciddi el yaralanması vakaları : Retrospektif çalışma
}

Severe hand injury cases in hazelnut farmers in Giresun: a retrospective study

\section{Umut Tuncel*}

Prof.Dr. A. İlhan Özdemir Devlet Hastanesi, Plastik Rekonstrüktif ve Estetik Cerrahi Kliniği, Giresun

\begin{tabular}{|c|c|}
\hline MAKALE BİLGİLERİ & ÖZET \\
\hline Makale Geçmişi: & \multirow{11}{*}{$\begin{array}{l}\text { Bu çalışmada Giresun ilinde findık tarımının aktif olarak yapıldığı Temmuz ve Ağustos } \\
\text { aylarında artan ciddi el yaralanma vakaları gözden geçirildi. Bu amaçla 2006-2008 yılla- } \\
\text { r1 Temmuz ve Ağustos aylarında hastanemize ciddi el yaralanması ile başvuran } 70 \text { hasta } \\
\text { retrospektif olarak incelendi. Hastalar yaş, cinsiyet, yaralanmanın tipi, tedavinin şekli ve } \\
\text { fonksiyonel sonuçlar açısından değerlendirildi. Hastaların 51'i erkek, 19'u bayandı ve yaş } \\
\text { dağılımı 20-65 arasında değişti. Vakaların 20'sinde cilt defekti, 40'ında ise kompleks yu- } \\
\text { muşak doku defekti mevcuttu. } 45 \text { vakada parmak amputasyonu mevcut olup bunların } 32 \text { 'si } \\
\text { Distal İnterfalangeal Eklem (DİP) düzeyinden ve 24'ü birden fazla parmak amputasyonu } \\
\text { şeklindeydi. 22'vakada ise amputasyon parsiyeldi. Kompleks yumuşak doku defekti olan } \\
\text { hastalara birden fazla sayıda operasyon uygulandı. Tam ya da kısmi ampute parmak vaka- } \\
\text { larında, replantasyona uygun } 6 \text { vaka dışındakilere amputasyon ve güdük onarımı yapıldı. } \\
\text { Sonuç olarak bu ve benzeri çalışmalardan elde edilecek veriler 1şığında toplumda maddi ve } \\
\text { manevi kayıplara neden olan ciddi el yaralanmalarının önlenmesinin mümkün olabileceğini } \\
\text { düşünüyoruz. }\end{array}$} \\
\hline $29 / 12 / 2008$ & \\
\hline 07 / 09 / 2009 & \\
\hline * Yazıșma Adresi: & \\
\hline Umut Tuncel & \\
\hline Prof. Dr. A. İlhan Özdemir & \\
\hline Devlet Hastanesi, & \\
\hline Plastik Rekonstrüktif ve Estetik & \\
\hline Cerrahi Kliniği, 28200, Giresun & \\
\hline E-posta : drumuttuncel@gmail.com & \\
\hline $\begin{array}{l}\text { Anahtar Kelimeler: } \\
\text { Tarım İscileri }\end{array}$ & \\
\hline
\end{tabular}

El Yaralanmaları

Kazalar

Endüstriyel Kazalar

Fleksör Tendon Yaralanmaları

Ekstansör Tendon Yaralanmaları

Key Words:

Farm Workers

Hand Injuries

Accidents

Industrial Accidents

Flexor Tendon Injuries

Extansor Tendon Injuries

\begin{abstract}
In this study, we analized severe hand injury cases that were frequently seen between June and August months in Giresun. Seventy patients with severe hand injuries that had been admitted to our hospital in 2006-2008 were handled retrospectively. Patients were explored according to sex, pattern of injury, type of treatment and functional results. 51 patients were men and 19 were female. Age pattern was 20-65 year. Skin defects were in 20 cases, complex soft tissue injuries were in 40 cases. 45 cases with digital amputations were seperated as single, multiple, complet, partial, from distal interphalangeal joint (DIP), proximal (PIP) and metacarpophalangeal joint (MCP) level. 32 cases were from DIP level. In 24 patients, amputation was multiple and 22 amputation cases were partial. Patients with complex soft tissue injuries were treated by multi-stage operations. In total or partial digital amputation cases, only six cases were performed replantation. The other amputation cases were treated by stump reconstruction. In conclusion, in light of the obtaining this knowledges from the literature, it has been opinion would be able to prevent severe hand injuries those giving rise to important spiritual and material losses in societies.
\end{abstract}

J. Exp. Clin. Med., 2009; 26:68-71

(C) 2009 OMÜ Tüm Hakları Saklıdır.

\section{Giriș}

El üst ekstremitenin en aktif bölümü olup, günlük işlerimizi yapmamızda bize en çok gerekli olan organımızdir (Keskin ve ark., 2005). Bu sebeptendir ki insan vücudunun en sık yaralanmaya maruz kalan bölümü olarak durmaktadır. Günümüzde acil servislere yaralanma nedeniyle başvuran vakaların yaklaşık \% 20'si el yaralanmasını içermektedir. El yaralanması vakaları endüstriyel gelişmişlik- le doğru orantılı olarak artış göstermekte olup, bizim çalışmamızda görüldüğü gibi halen daha primitif cihazlarla çalışan tarım kesiminden insanları daha çok etkilemektedir. Yaralanmalar çoğunlukla genç erkeklerde ve dominant elde görülmektedir (Nieminen ve ark., 1981). Endüstriyel alanda çalışan işçilerde görülen el yaralanma vakaları daha çok ağır iş makineleri ve kesici aletlerle geliştiğinden infekte ve kirli yaralar olarak karşımıza çıkmaktadır (Clark 
ve ark., 1985). Genel olarak el yaralanmaları hayati tehlike yaratmamakla beraber, önemli fonksiyonel kayıplar, iş gücü kayıpları ve maliyeti yüksek tedavi şekilleri ile hayat boyu özürlülükle sonuçlanması açısından da oldukça önem arz etmektedir (Nieminen ve ark., 1981; Keskin ve ark., 2005). Bu nedenle değerlendirilmesi ve tedavisi kadar, el yaralanması olasılığ yükssek iş kollarında çalışan insanların bilinçlendirilmesi de ayrı bir önem taşımaktadır.

$\mathrm{Bu}$ retrospektif çalışmada hastalar yaş, cinsiyet, yaralanmanın tipi, tedavinin şekli ve fonksiyonel sonuçlar açısından incelenirken, el yaralanmasına maruz kalma olasılığı yüksek iş kollarında çalışan insanların bilinçlendirilmesinin önemi vurgulanmıştır.

\section{Araştırma Yöntemi}

Çalışmada 2006-2008 yılları arasında Giresun Prof. Dr. A. İlhan Özdemir Devlet Hastanesi acil servisi veya poliklinik yoluyla başvuran ve yatarak tedavi görmüş 70 ciddi el yaralanması vakası retrospektif olarak analiz edildi. Çalışma Helsinki Deklarasyonuna uygun olarak gerçekleştirilmiştir.

Hastalar yaş, cinsiyet, yaralanmanın tipi, tedavinin şekli ve fonksiyonel sonuçlar açısından değerlendirildi. Sadece lokal yara bakımı veya basit yumuşak doku travmalı olup konservatif takip edilen hastalar çalışma kapsamına alınmadı. Yaralanmanın tipi kapsamında hastalar, cilt defektli olanlar, kompleks yumuşak doku defektli olanlar, amputasyon ile gelenler ve tendon yaralanmasi olanlar şeklinde ayrıldı. Cilt ve kompleks yumuşak doku defektiyle gelen hastalar primer sütüre edilenler, cilt grefti uygulananlar ve flep cerrahisi gerektirenler olarak siniflandırıld. Amputasyon vakaları, tam, parsiyel, tekli ve çoklu amputasyon olarak incelendi. Ayrıca bu vakalar replantasyon yapılanlar ve güdük onarımına gidenler olarak ta analiz edildi. Tendon yaralanmaları ekstansör, fleksör ve kompleks olarak üç grupta ele alındı.

Fonksiyonel sonuçlar çok iyi, iyi, orta ve kötü olarak değerlendirildi. Kriter ise hastanın günlük aktivitelerinde elini kullanabilirliği idi.

\section{Bulgular}

Çalışamaya alınan 70 ciddi el yaralanma vakasının 51'i erkek (\%72) 19'u kadındı (\%27). Yaş aralığı 2065 arasında olup yaş ortalaması 42 idi (Tablo 1). Buna göre ciddi el yaralanması vakalarında 46-55 yaş grubunda diğer yaş gruplarına göre belirgin bir artış olduğu görüldü. $\mathrm{Bu}$ yaş grubundaki erkek hastaların toplam erkek hastalara oranı \%29,41 iken, kadın hastalarda toplam kadın hastalara göre oran \%36,84 tü (Şekil 1). Cinsiyet ve yaralanma tipi karşılaştırıldığında yumuşak doku yaralanmalarında 22 hasta erkek 10 hasta kadın ve tendon yaralanmalarında 29 hasta erkek, 9 hasta kadın olarak gözlendi. Oranlandığında ise yumuşak doku yaralanmasında erkek hasta oran $1 \% 68,75$ kadın hasta oran $1 \% 31,25$ ve tendon yaralan- malarında erkek hasta oran $\% 76,32$ ve kadın hasta oran 1 \%23,68 şeklindeydi (Şekil 2).

Sadece yumuşak doku yaralanması vakalarının sayıs1 31 olup, bunların 20'sinde cilt defekti $(\% 62,5)$, 11 'sinde $(\% 37,5)$ kompleks yumuşak doku defekti mevcuttu (Tablo 2). Sadece cilt ve kompleks yumuşak doku defektlerinde yine erkek hastaların daha fazla olduğu gözlendi (Şekil 3). Bu vakaların 12'sinde tedavi primer sütür iken, 10'unda cilt grefti gerekti. Flep uygulamas1 gerektiren vakaların 6'sinde lokal flep, 4' ünde random patern flep operasyonu uyguland.

Amputasyonla gelen el yaralanması sayıs1 45 idi. Total amputasyonlar 23, k1smi amputasyonlar 22 idi. Amputasyon düzeyi 32 vakada distal interfalangeal eklem, 10 'u proksimal interfalangeal eklem ve 3'ü metatarsofalangeal eklem düzeyindendi. Çoklu amputasyon sayısı 24, tekli olanlar 22 idi. Yalnızca uygun 6 vakada replantasyon ya da revaskülarizasyon denendi. Bu vakaların 2'si 1.parmak, 1'i 2. parmak, 2'si 3. parmak ve 1'i 5.parmakta olup, toplam 6 vakada da amputasyon seviyesi proksimal interfalangeal eklem proksimali düzeyindeydi. Sadece 2. parmaktaki amputasyon total olup, diğerleri subtotaldi. Fakat subtotal olanlarda da her iki taraf bundle'ın kesik olduğu gözlendi. 6 vakanın 4'ü başarılıydı. Başarısız olan toplam 2 adet, 3. ve 5. parmak revaskülarizasyon vakas1 ise sekonder cerrahi ile erken postoperatif dönemde uygun şekilde kapatıldı. Kalan 39 vakada ise çeşitli doku örtümü metodlarıyla güdük onarımı cerrahisi uygulandı.

Çalışmada analiz edilen hastaların 39'unda tendon kesisi mevcuttu (Tablo 2). Tendon yaralanma vakalarının 22'sinde ekstansör tendon kesisi olup, bu vakaların 13'u tam, 9'u k1smi kesikti. 11 vakada fleksör tendon kesisi

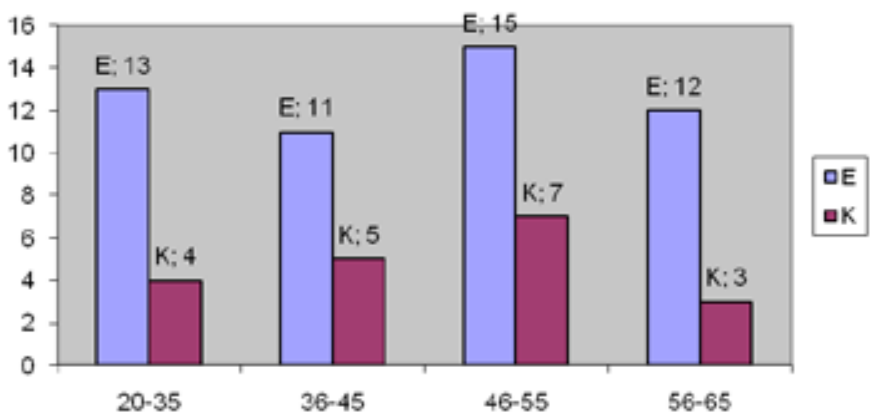

Şekil : 1 : Yaş gruplarının cinsiyete göre dağılımı

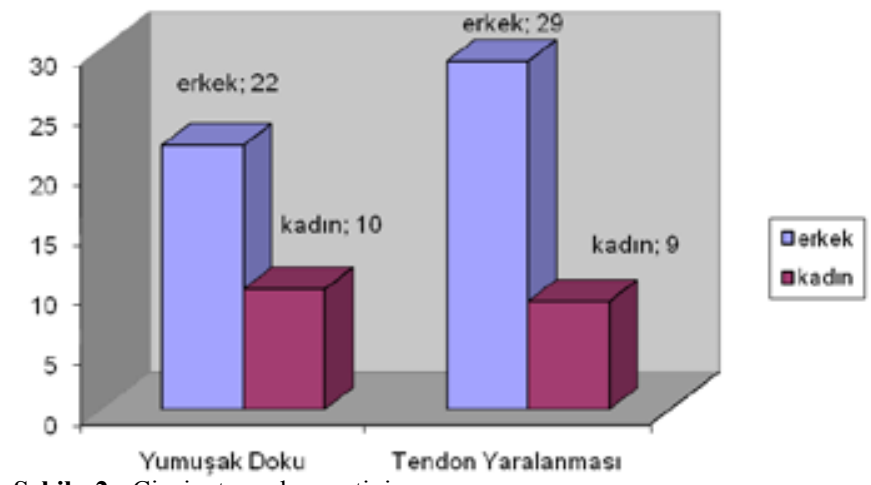

Şekil : 2: Cinsiyet yaralanma tipi 
Tablo : 1: Demografik veriler



Tablo : 2: Yaralanma tipi

\begin{tabular}{|c|c|c|c|c|c|c|c|c|c|}
\hline \multirow{3}{*}{$\begin{array}{l}\text { YARALANMA } \\
\text { TİPİ }\end{array}$} & \multicolumn{2}{|c|}{$\begin{array}{l}\text { YUMUŞAK } \\
\text { DOKU }\end{array}$} & \multicolumn{7}{|c|}{ TENDON } \\
\hline & \multirow{2}{*}{ CİLT } & \multirow{2}{*}{ KOMP } & \multicolumn{2}{|c|}{$\overline{\mathrm{ET}}$} & \multicolumn{2}{|c|}{ FT } & \multicolumn{2}{|c|}{$(\mathrm{E}+\mathrm{F}) \mathrm{T}$} & \multirow{3}{*}{ TOPLAM } \\
\hline & & & TK & $\mathrm{KK}$ & $\mathrm{TK}$ & $\mathrm{KK}$ & TK & $\mathrm{KK}$ & \\
\hline $\mathrm{n}$ & 20 & 11 & 13 & 9 & 4 & 7 & 2 & 4 & \\
\hline TOPLAM & \multicolumn{2}{|c|}{31} & \multicolumn{4}{|c|}{39} & & & 70 \\
\hline
\end{tabular}

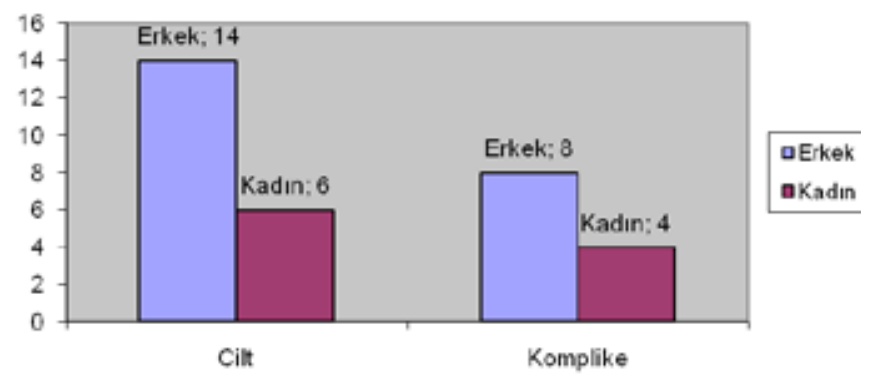

Şekil : 3: Yumuşak doku yaralanmalarının cinsiyete göre dağılımı

tespit edilmiş olup, 6 vakada ekstansör ve fleksör tendon yaralanması birlikteydi. Vakaların hiçbirisinde sekonder cerrahiye gerek duyulmadi. Bir hafta boyunca uygulanan statik atelin ardında, erken fizik tedavi amaciyla dinamik atel uygulamasına geçildi. Yaklaşık 4. haftadan itibaren hastalar ellerini kullanmaya başladı ve sonuçlar oldukça yüz güldürücüydü.

Son olarak da hastanın opere edilen elini günlük aktivitelerinde kullanabilirliği doğrultusunda sonuçlar çok iyi, iyi, orta ve kötü olarak değerlendirildi (Şekil 4). Buna göre 40 vakada sonuç çok iyi, 12 vakada iyi, 15 hastada orta ve 3 vakada ise kötüydü.

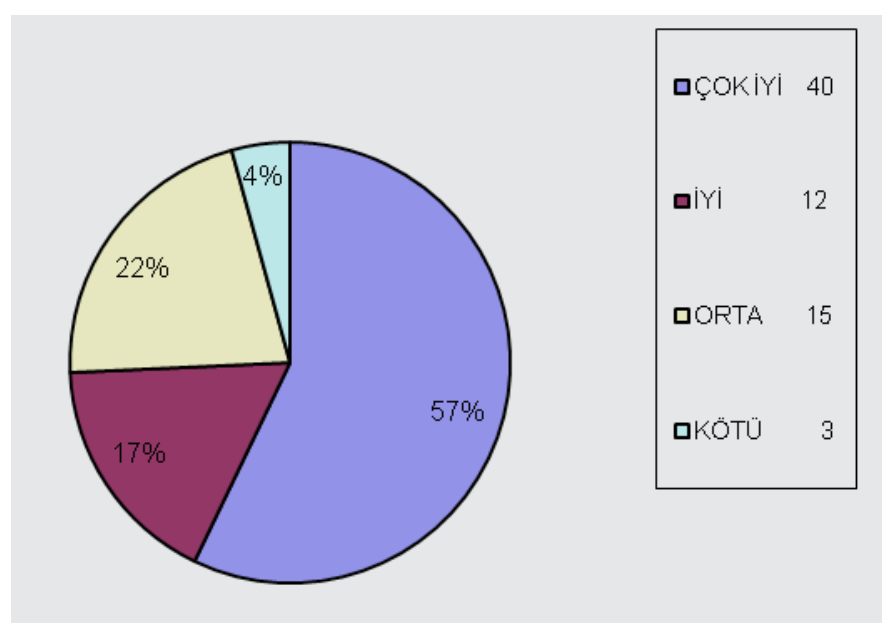

Şekil : 4: İyileşme derecesi

\section{Tartışma}

Elimiz günlük yaşantımızda fiziksel aktivitelerimizde en çok kullandığımız ve bu nedenle de en çok yaralanmaya maruz kalan organımızdır (Keskin ve ark., 2005). Akut travmatik el yaralanmaları en çok iş yerlerinde, $\% 76$ oranında erkek, \%23 oranında kadın iş̧̧ilerde gelişmektedir (Sorock ve ark., 2002). Ülkemizde yapılan çalışmalarda Dinçer ve ark., (Dinçer ve ark., 1998) erkek/kadın hasta oranını 5/1, Ergüner ve ark., (Ergüner ve ark., 2002) erkek popülasyon oranını \%70, Altan ve ark., (Altan ve ark., 2002) ise \%84,8 olarak bildirmişlerdir. Bizim çalışmamızda ise bu oran \%63 ile erkek hasta lehine idi. Bunun nedeni sanayi alanında olduğu gibi tarım kesiminde de çalışan insanların erkek ağırlıklı olmasından kaynaklandığı düşünüldü.

Acil servislere iş kazası nedeniyle başvuran hastalar en sık 20-44 yaş grubundandır (Jackson, 2001). Nieminen ve ark., (Nieminen ve ark., 1981) erkek hastalarda en sik 4. dekatta, kadın hastalarda ise en s1k 5. dekatta el yaralanması görüldüğünü, başvuranların \%14'ünün 15 yaşın altında, \%8'inin ise 65 yaş üzerinde olduğunu bildirmişlerdir. $\mathrm{Bu}$ oranlar ve literatürdeki diğer oranlar bizim çalışmamızda elde ettiğimiz oranlarla örtüşmekte olduğu görüldü. Bize başvurmuş olan vakalarda da yaş grubu 2065 arasında değişmekte ve erkek hasta ağırlıktaydı.

Altan ve ark.'nın (Altan ve ark., 2002; Keskin ve ark., 2005) yaptığ 1 çalışmalarında iş yaralanmalarının oranı $\% 45$ olarak bildirilmiş, bunun iş yerlerinde alet ve makinelerinin bakım, yenileme ve iş güvenliği açısından istenen standartta olmaması ve iş deneyimine sahip olmayan genç işçilerin küçük ve orta ölçekli iş yerlerinde yüksek oranda çalışıyor olmasından kaynaklandığı belirtilmiştir. Literatürde dominant el yaralanması vakaların \%53-60'ında görülmektedir (Sorock ve ark., 2002; Altan ve ark., 2002; Keskin ve ark., 2005). Dominant el daha fazla yaralanma riski taşımakta, ancak literatürde bu konuda yapılmış yeterli çalışma bulunmamaktadır (Keskin ve ark., 2005).

Alsound ve ark. iş kazaları sonucu gelişen el yaralanmalarını inceledikleri çalışmalarında \%28'inin makine, $\% 14$ 'ünün inşaat, $\% 7,5$ 'inin araç sürücülerinde görüldügünü bildirmişlerdir (Keskin ve ark., 2005; Nieminen ve ark., 1981). Avustralya'da iş kazaları nedeniyle gelişen el ve bilek yaralanmalarının en çok delici ve kesici alet yaralanması sonucu meydana geldiği, meslek grubu olarak en çok kasap, makine operatörleri, marangozlar ve kesici alet kullanan işçilerin yaralandığ 1 bildirilmiştir (Keskin ve ark., 2005). Ergüner ve ark.'nın çalışmalarında ise tendon yaralanmalarının \%37'sinin işçilerde görüldüğü, iş ve ev kazalarının ise $\% 30$ oranında görüldüğü bildirilmiştir (Ergüner ve ark., 2002).

Literatürden de anlaşılacağı üzere yapılan çalışmalar daha çok endüstriyel toplumları içerdiğinden, tarım alanında çalışan popülasyonla ilgili veriler yetersizdir. Bizim ülkemizde ve özellikle de bölgemizde tarımın, insanların 
hayatında halen çok önemli bir rol oynaması, kısıtlı ekonomik imkanlar, tarım ürünü çeşitliliğindeki alternatifsizlik ve zorlu coğrafik şartlar nedeniyle önemli oranda el yaralanmalarını içeren kazalar olabilmektedir.

Karasoy ve ark.'nın yaptığı diğer bir çalışmada el yaralanmalarının nedeni $\% 40$ oranında iş kazası şeklinde olup, \%35 ile izole cilt kesileri ilk sırada yer almıştır. Yaralanmaların \%22 sinde tendon, \%15'inde ise kombine el yaralanması tespit edilmiştir (Karasoy ve ark., 1998). Literatürde de cilt kesilerinin oran1 \%35-45 arasında değişmektedir. Özgenel ve ark.'ın yaptığı bir başka çalışmada traktör nedeniyle el yaralanması olan 70 vaka incelenmiş ve benzer oranlar gözlenmiştir. Bu çalışmada 20 vakada greft gerektirmiş, 40 vakada ise kompleks yumuşak doku yaralanması nedeniyle çeşitli flep cerrahisi tekniklerine başvurulmuştur. Yine bu çalışmada kısmi ve total amputasyonla gelen vaka sayıs1 50 olup, hemen hepsinde erken dönemde revaskülarizasyon denenmiş ancak yüksek oranda başarısızlıkla sonuçlandığ amputasyon vakasındaki replantasyonlarda ise başarı oranı $\% 75$ düzeyinde olup, bu başarı oranı amputasyonların genelde subtotal olması ile de açıklanabilir. Total fonksiyonel sonuçlarda ise sonuçların iyi olduğu, hastaların günlük aktivitelerinde ellerini kullanmalarında başarılı oldukları belirtilmiştir. Literatürle karşılaştırıldığında bizim çalışmamızda elde ettiğimiz sonuçlar oldukça benzerlik göstermekte olup, Plastik Rekonstrüktif Cerrahinin ilimizde yeni bir branş olması nedeniyle tedavi şekli ve hastaların takibi konusunda bazı farklar olmasını doğal olarak görmekteyiz.

Sonuç olarak ciddi el yaralanmalarının görülme riski yüksek olan diğer alanlarda olduğu gibi tarım alanında çalışan insanların da bu konuda bilinçlendirilmesi, hem ülkemize hem de bölgemize yönelik yaralanma koşullar1nın belirlenmesi ile iş gücü ve maddi kayıpların önüne geçilebileceğini düşünmekteyiz.

\section{KAYNAKLAR}

Altan L., Bingöl Ü., Selçuk A., Özkan N., 2002., El yaralanmalı hastaların sosyodemografik özellikleri ve yaralanmanın karakteristik özelliklerinin rehabilitasyon sonuçlarına etkisi. Romatol Tıp Rehab 13, 236-242.

Clark D. P., Scott R. N., Anderson I. W. R. 1985. Hand problems in an accident and emergency department. J. Hand. Surg. 10, $297-$ 299.

Dinçer F., Çetin A., Çeliker R., Çetin M. 1998. Causes and consequences of hand injuries requiring hand rehabilitation. Eur. J. Phys. Med. Rehabil. 8, 113-115.

Ergüner H., İnanır M., Dursun N., Dursun E. 2002. Travmatik el yaralanmalı hastalarımızın klinik özellikleri. Romatol. Tıp Rehab. $13,243-251$

Jackson LL., 2001. Non fatal occupational injuries and illnesses treated in hospital emergency department in the United States. Inj. Prev. 7, 121-126.

Karasoy A., Sakinsel A., Gözü A., Kuran İ., Baş L. 1998. Acil el yaralanmalarında deneyimlerimiz. Ulusal Travma Acil Cerr. Derg. 4, 265-269.

Keskin E. D., Bodur H., Sevil A., Erdoğan B., Akyüz M. 2005. Tendon yaralanmalı hastalarımızın klinik özellikleri. Türk Fiz. Tıp Rehab. Derg. 51, 94-97

Nieminen S, Nurmi M, Isberg U. 1981. Hand injuries in Finland. Scand. J. Plast. Reconstr. Surg. 15, 57-60.

Özgenel G., Y., Akın S., Özbek S., Kahveci R., Özcan M. 2008. Çocuklarda traktöre bağlı ciddi el yaralanmaları: 70 olgunun sunumu. Ulusal Travma Acil Cerr. Derg. 14, 299-302.

Sorock GS, Lombardi DA, Hauser RB, Eisen EA. 2002. Acute traumatic occupational hand injuries: Type, location and severity. J. Occup. Environ. Med. 44, 345-351. 